\title{
THE INDUSTRY IN POLAND AGAINST A BACKGROUND OF STRUCTURAL CHANGES IN THE WORLD INDUSTRY
}

Since the first industrial revolution, the main driving force of the socioeconomic development have become the innovations, i.e. changes in the readymade products and the production processes based on the new or so far not exploited knowledge.

After nearly two hundred years, in the second half of the current century, the highly industrialized countries of Western Europe, U.S. and Japan entered into a new phase of development called the Fourth Industrial Revolution which is marked by the structural changes in industry, and particularly by the growing role of the high technology industries ${ }^{1}$.

The observation of the hitherto process of development of the high technology industries in the highly industrialized countries in which their share of the overall employment in industry amounts to $8-12 \%$, in the industrial production -12 $18 \%$ and in exports - 20-30\%, confirms that the high technology industries are the principal factor dynamizing the development of the economy as a whole.

It chiefly can be seen on the example of electronics which makes up to 50-75\% of their production and whose share in the ready-made products is a decisive factor in being competitive in the world market. As early as at the outset of the 80-ies, the annual rate of the world production of the electronic products significantly exceeded the rate of growth of the overall industrial production, and the output of the integrated circuits per one inhabitant became one of the fundamental indices of the development of industry, the same as output of steel or electric power had been earlier. The development of electronics and hereafter microelectronics applied in informatics, scientific research apparatus, telecommunication gear, mass media, medical

\footnotetext{
'As the univocally and generally recognized criteria of distinguishing the high technology industries have not yet been worked out, this article lists among them the manufacturing of: electronic products of the microelectronic area, informatic apparatus, scientific-research instruments, telecommunications equipment, television gear and mass-media equipment, medical instruments and appliances, industrial automatics equipment, machines (lathes) numerically controlled, industrial robots and manipulators, some other products of electro-mechanical industry (for example, airplanes), pharmaceuticals and engineering materials.
} 
instruments and appliances, industrial automatic control gear and in transportation-has created a qualitatively new epoch of technical civilization.

In Poland, the share of the high technology industries in the overall employment in industry amounts now to $1.5 \%$, in the industrial production $-2.1 \%$ and in exports $2.0 \%$. Like in highly industrialized countries, more than half of their output falls to the electronics yet its share in creation of the national income is almost five times lower.

This is a consequence of the current industrial policy favouring the development of heavy industry. Such a policy was carried out in the 50-ies and 60-ies when Poland's industrial base was under construction, as well as in the 70-ies when the possibility of modernization of industry with the use of foreign credits emerged. The economic reforms launched in 1982 created new conditions for the functioning of industry, but did not result in setting in motion the economic mechanism which would induce enterprises to make innovations, and by the same token to join the stream of processes that characterize world industry. In the years 1983-87 the share of heavy industry in the all-national investment outlays continued to be high and totalled $19.7 \%$, while the joint share of the high technology industries, national education and science amounted to $4.8 \%$.

The structure of industry in Poland is characterized by predominance of traditional branches, among them chicfly fuel-power-metallurgy industries whose participation in the global employment in industry totals $18.3 \%$, in the industrial production $-21.5 \%$ and in exports $-22.4 \%$.

This kind of structure of industry does not favour innovations because in many branches of heavy industry the traditional factors of production can be utilized, that is unqualified manpower (for example, peasant workers), and machinery and production facilities of low or medium technical standard (for example, simple machine tools (lathes), open-hearth furnaces). True enough, it makes possible a mass production, but of produce of high consumption of materials and power, and having low exploitation parameters.

Likewise, it does not foster the entering of Poland into the system of modern links with the global market through participation in the international industrial cooperation. As the cooperation is preferred in those branches of industry in which frequent assortment changes are being done (new generations of products appear), it is an essential way of the transfer of innovations. The participation of the industrial cooperation in Poland's exports amounts barely to $15.0 \%$, while in exports of highly industrialized countries it totals $40-50 \%$.

The significant influence is exerted here by the insufficient contribution to the Polish industry of the small industrial enterprises ${ }^{2}$ that are particularly predisposed to undertaking the cooperation because of their characteristic feature namely production resilience, i.e. ability to quickly change a profile of production.

\footnotetext{
2 Because the term of small industry has not yet been univocally defined, in the international comparisons conceming this term most frequently enterprises employing up to 100 persons are included in it.
} 
In the hitherto applied industrial policy of preference for development of heavy industry, the concept of the development of small industry was non-existent. It led to the generalizing of the small industry notion as the economic activity that represents the traditional branches, in particular light and metallurgic industry, and the one that uses machines and production facilities of low technological standards.

However, in the highly industrialized countrics small industry plays an ever increasing role in high technology industries. In many of them, the small enterprises are seen as a source of continuous renewal of industry, economic dynamism and high competitiveness. Their innovatory character comes out of exceptionally favourable conditions for the creative activity developed as a result of cooperation, mutual assistance and intellectual mobilization of the small group of labourers.

This can be specially seen on the example of small research-production enterprises of the electronic industry established around the scientific research centres and characterized by innovative aggresiveness, for example Stanford University in California, Cambridge University in England and Harvard University in Massachusetts.

The cooperation of scientific researchers and highly qualified employees of industry permits a rapid introduction of innovations and considerable shortening of the period of time from the moment of their acquisition to putting them into practical use.

The high technology industries like the traditional branches show the tendency for the spatial concentration, and the principal factors of their location are: highly qualified manpower, scientific research institutions, education of personnel and existence of communications infrastructure (road and air transportation, intercommunication). The essential factor for location is also not-transformed and not-polluted natural environment which makes it possible to manufacture produce of the highest quality (for example, integrated circuits). As the environment of this kind is also preferred by highly qualified workers of science and industry as their place of work and dwelling - the industrial centres of the youngest generation, the so-called silicon landscapes, are founded as a rule beyond the old centres grouping traditional branches. This is evidenced by a large-scale development of the electronic industry in the attractive, in respect of landscape, regions of California, Texas, Southern England, the Kiusiu Islands, Bavaria and Côte d'Azur.

In Poland, in spite of the existence of regions in which the natural environment is particularly favourable for the production of electronic sub-assemblies, for example the middle part of the Pomerania Lakeland, the greatest concentration of the electronic industry exists in the Warsaw Industrial District. The contribution of Warsaw and smaller towns situated in its suburban zone, for example Blonie and Piaseczno to the country's production of the electronic industry comes almost to $60.0 \%$. Warsaw Industrial District concentrating $43.0 \%$ of the country's employment in scientific research and technological development has 
the most modern structure of industry in Poland because besides electronics it has developed manufacturing of other products counted among the high technology industries: industrial automatic equipment, scientific research apparatus, medical instruments and equipment, numerically controlled machines, industrial robots and pharmaceuticals.

The negative phenomenon in distribution of high technology industries in Poland is their little participation in the industry of regions dominated by traditional branches, among them in particular:Upper Silesia (fuel-power and metallurgic industries), of Łódź (light industry) and Sudetes (fuel-power and light industries).

The necessity of diminishing the economic dependence of these regions on the branches considered as declining industries requires a development of industries which would create the possibilities of employment. The experience of the highly industrialized, market economy countries, including structural changes in the Scottish industry (Glasgow, Edinburgh) and in Oregon (Portland) indicates that such possibilities, besides the modernization of the industries already in existence (for example, curtailment of the raw materials production in the metallurgical industry for the benefit of production of the highly refined ready-made products) - are created first of all by the development of high technology industries.

The comparison of the shares of high technology industries in Poland's industry with those of highly industrialized market economy countries points out to the existence of technological gap. Hence a lock of market balance in respect of supply of the homemade means of production and consumption articles of lasting use which would represent new technology generations, and their little competitive value in the world market.

Leveling off the technological gap depends on effecting the structural changes in the Polish industry consisting in the gradual departure from the traditional branches of capital-intensive character (for example, a classical production of steel, the primary stages of transformation of chemical raw materials) to the modern branches of intellectual-intensive character i.e. containing the considerable load of knowledge (high technology industries).

Their range is, however, limited by the shortage of financial means that makes impossible a large-scale application of the classical tools of industrial policy such as flexible tax policy and preferential credits. Therefore, the essential role in putting an end to the technological gap should be played by foreign capital, through direct investment and by means of founding of companies with its participation as well. Another argument for taking advantage of this form ui modernizing of the Polish industry is the possibility of gaining access to the global market in which foreign partners are already present. 